\title{
Effects of Dry Period Length on Milk Production and Health of Dairy Cattle
}

\author{
R. D. Watters, ${ }^{\star 1}$ J. N. Guenther, ${ }^{\star}$ A. E. Brickner, ${ }^{\star}$ R. R. Rastani, ${ }^{\star 2}$ P. M. Crump, ${ }^{\star}$ \\ P. W. Clark, $†$ and R. R. Grummer ${ }^{\star 3}$ \\ ${ }^{*}$ Department of Dairy Science, University of Wisconsin, Madison 53706 \\ †Department of Animal and Food Science, University of Wisconsin, River Falls 54022
}

\begin{abstract}
Holstein cows $(\mathrm{n}=781)$ in a commercial dairy herd were used in a randomized design to evaluate 2 dry period (DP) management strategies on milk production, milk components, milk quality, colostrum quality, and incidence of metabolic disorders. Cows were randomly assigned to a traditional $55 \mathrm{~d}(\mathrm{~T})$ or shortened $34 \mathrm{~d}(\mathrm{~S})$ DP. Cows assigned to T were fed a low-energy diet until $34 \mathrm{~d}$ before expected calving at which time all cows were fed a moderate-energy transition diet until calving. Postpartum, cows assigned to $\mathrm{T}$ produced more milk and tended to produce more solids-corrected milk than cows on S. Treatment differences in milk and solids-corrected milk yield were accounted for by cows in their second lactation. Milk fat percentage did not differ between treatments, but milk protein percentage was greater for cows assigned to S. Colostrum quality measured as IgG concentration did not differ between management strategies. Somatic cell score and cases of mastitis were not affected by management strategy. There was a tendency for prepartum nonesterified fatty acid (NEFA) to be lower for cows assigned to T compared with S. However, postpartum, cows assigned to $\mathrm{S}$ had significantly lower NEFA concentrations than those assigned to $\mathrm{T}$. The incidences of ketosis, retained placenta, displaced abomasum, and metritis did not differ between treatments. Postpartum energy balance, as indicated by plasma NEFA, may have been improved for cows assigned to $\mathrm{S}$; there was no detectable effect on animal health.
\end{abstract}

Key words: dry period length, animal health, milk yield, milk composition

\section{INTRODUCTION}

Recently, there has been an interest in shortening the non-income-producing dry period (DP). Retrospective

Received August 14, 2007.

Accepted February 11, 2008.

${ }^{1}$ Current address: Cornell University, Ithaca, NY 14853.

${ }^{2}$ Current address: MSC Specialty Nutrition, Dundee, IL 60118.

${ }^{3}$ Corresponding author: rgrummer@facstaff.wisc.edu analysis of farm data and planned experiments both indicate about a 5 to $6 \%$ loss in milk yield during the subsequent lactation when the DP is reduced by approximately $30 \mathrm{~d}$ (Bachman and Schairer, 2003; Rastani and Grummer, 2006). Additional milk produced during the extra $30 \mathrm{~d}$ of lactation can compensate for some of the loss in the subsequent lactation (Bachman and Schairer, 2003; Gulay et al., 2003; Rastani et al., 2005). However, the decision to shorten the DP should depend on factors beyond maximization of milk yield. Effects of DP length on economically important parameters such as cow health and reproduction must also be considered (Gümen et al., 2005).

Length of the DP affects the energy status of periparturient cows (Rastani, 2005; Rastani et al., 2005). Postpartum energy balance (EB) was increased and plasma NEFA and liver triglyceride concentrations were lower when the length of the DP was shortened from 56 to $28 \mathrm{~d}$ (Rastani et al., 2005). Negative energy balance (NEB) may be related to incidences of health disorders such as fatty liver and ketosis (Bertics et al., 1992; Goff and Horst, 1997). Some studies have associated BCS, an indicator of energy status, with the risk of disease (Gearhart et al., 1990; Ruegg et al., 1992). Factors that reduce DMI and compromise energy intake around calving increase the risk for metabolic diseases (Goff and Horst, 1997; Hayirli and Grummer, 2004).

There is limited information on the effect of DP length on incidences of health disorders because large animal numbers are required to have sufficient statistical power to detect treatment differences. To assess the effect of shortening the DP on animal health requires the use of a large commercial dairy or several dairies because university herds are typically small and do not facilitate needed replication (Kuhn and Hutchison, 2005). Only one study has utilized multiple farms to determine the effect of DP length on animal health (Coppock et al., 1974). Coppock et al. (1974) indicated that DP lengths of $20,30,40,50$, and $60 \mathrm{~d}$ had no effect on the incidence of ketosis, milk fever, or retained placenta. However, this study was conducted over 30 yr ago on what today would be considered low-produc- 
ing cows $(<7,000 \mathrm{~kg} / \mathrm{yr})$. Therefore, the objective of this experiment was to determine the effect of a short DP management strategy on milk production and animal health in a large commercial dairy herd. It was hypothesized that shortening the DP would improve animal health status by reducing the incidence rate of ketosis, metritis, retained placenta (RP), and displaced abomasum (DA).

\section{MATERIALS AND METHODS}

\section{Experimental Protocol}

Seven hundred eighty-one $(n=781)$ Holstein cows from a 3,000-cow commercial dairy were enrolled in this experiment. At $170 \mathrm{~d}$ of gestation, cows were selected for the experiment if they were producing $\geq 18 \mathrm{~kg}$ of milk/ $\mathrm{d}$ and were less than 400 DIM. Cows were randomly assigned to a traditional 55-d DP (T) or a shortened 34-d DP (S) management strategy. Previous lactation 305-d mature-equivalent (305ME) milk yield was not different between animals assigned to treatments $\mathrm{T}$ and $\mathrm{S}(13,615 \pm 137$ vs. $13,707 \pm 180 \mathrm{~kg} / \mathrm{yr} ; P=0.69)$, respectively. All cows were in their second gestation (i.e., in their first lactation and approaching their first DP) or greater at the time of selection. There were 426 cows that were in their first lactation and 355 in their second or greater lactation at the time they were assigned to the trial. Bovine somatotropin was administered to cows on both treatments. Visual inspection, primarily for BCS, was used to determine which cows would receive bST; cows did not receive bST past 170 $\mathrm{d}$ of gestation. All cows were milked 3 times each day except during the first 30 DIM when they were milked 4 times daily. Cows assigned to the trial were monitored from dry-off through parturition and until 300 DIM, when the trial ended. The University of WisconsinMadison, College of Agriculture and Life Sciences, Animal Care and Use Committee approved the experimental protocol.

Cows were dried off over a 24 -h period that involved 2 milkings. Cows were milked once and then returned to a pen with no access to water. The diet was altered by adding straw and was lower in energy than the diet fed to lactating cows. Twenty-four hours after the first milking, cows returned to the parlor for a final milking and dry cow treatment. The dry treatment was an intramammary antibiotic designed for cows $(10 \mathrm{~mL} /$ quarter of Cepharin Benzathine; Fort Dodge Animal Health, Fort Dodge, IA) and an internal teat sealant (Orbeseal; 65\% bismuth subnitrate/quarter; Pfizer Pharmaceuticals Group, Pfizer Inc., New York, NY).

Cows were fed a TMR formulated by the herd manager to meet or exceed nutrient requirements as indi- cated by NRC (2001; Table 1). Dry matter content of corn silage and alfalfa silage was determined twice weekly to keep the DM ratios of feeds constant. Diets were fed at $0900,0945,1200$, and $1300 \mathrm{~h}$. At $55 \mathrm{~d}$ before expected calving, cows assigned to $\mathrm{T}$ were fed a lowenergy diet until $35 \mathrm{~d}$ before expected calving. Cows assigned to $\mathrm{S}$ were fed a lactation diet from 55 to $35 \mathrm{~d}$ before expected calving because they were still milking. Starting at $34 \mathrm{~d}$ before expected calving, all cows were fed a moderate energy diet until calving. At calving, all cows were moved to a postfresh pen and fed a postfresh lactation diet. The postfresh diet was fed until 30 DIM when a lactation diet was fed for the remainder of the trial.

\section{Sampling and Analysis}

Milk yield was measured twice monthly from calving through 100 DIM and once monthly from 100 to 300 DIM during a single milking on each day, and a daily milk volume was calculated (Fox Valley DHIA Milk Analysis Laboratory, Appleton, WI). Milk samples were collected once a month at 1 milking from calving until 100 DIM and analyzed for fat, protein, lactose, total solids, and SCC using infrared spectrometry (AOAC, 1999; Fox Valley DHIA Milk Analysis Laboratory). Colostrum was sampled at the first milking, stored at $-20^{\circ} \mathrm{C}$, and later analyzed for IgG concentration by single radial immunodiffusion using a commercial kit (VMRD Inc., Pullman, WA; Fleenor and Scott, 1981).

Samples of TMR were taken every other week and dried at $60^{\circ} \mathrm{C}$ for $48 \mathrm{~h}$ in a forced air oven to determine DM. Samples were ground in a Wiley mill (1-mm screen; Arthur H. Thomas, Philadelphia, PA), composited, and analyzed by wet chemistry for CP, ether extract, NDF, and ADF (University of Wisconsin Soils and Forage Analysis Laboratory, Marshfield, WI; National Forage Testing Association, 1993; Table 2). Feed samples were taken every other week and $100 \mathrm{~g}$ of each sample was composited to make one final feed sample for analysis.

Body condition scoring was performed weekly for each cow by the same individual starting at $3 \mathrm{wk}$ before expected calving and continuing until 10 wk postpartum. A scale value of 1 (very thin) to 5 (obese) with quarter increments was assigned to each cow (Wildman et al., 1982).

One blood sample was collected at $3 \mathrm{wk}(-21 \pm 5 \mathrm{~d})$ before expected parturition and another at $3 \mathrm{wk}(22 \pm$ $4 \mathrm{~d})$ after parturition. Samples were collected at the time of feed delivery from cows restrained in feed-line headlocks at $0900 \mathrm{~h}$ prepartum and $1300 \mathrm{~h}$ postpartum. Blood samples were collected into Vacutainer tubes (Becton Dickinson, Franklin Lakes, NJ) that contained potassium oxalate and sodium fluoride as a glycolytic in- 
Table 1. Ingredient composition of diets

\begin{tabular}{lcccc}
\hline & \multicolumn{3}{c}{ Diet $^{1}$} \\
\cline { 2 - 5 } Ingredient, \% of DM & LE & ME & Postfresh & Lactation \\
\hline Corn silage & 14.13 & 24.77 & 28.83 & 37.24 \\
Alfalfa silage & 0.0 & 17.11 & 19.83 & 16.79 \\
Ground corn & 0.0 & 12.16 & 8.89 & 12.93 \\
Corn gluten feed & 0.0 & 0.0 & 10.96 & 9.36 \\
SBM, 48\% CP & 0.0 & 9.41 & 8.33 & 6.84 \\
Alfalfa hay & 0.0 & 7.5 & 7.96 & 3.02 \\
Bakery byproduct & 0.0 & 7.6 & 4.97 & 1.3 \\
Blood meal & 0.0 & 0.0 & 0.32 & 6.89 \\
Cottonseed & 0.0 & 0.0 & 8.09 & 0.0 \\
Wheat straw & 31.14 & 19.91 & 0.0 & 0.0 \\
Weighbacks & 54.19 & 0.0 & 0.0 & 0.9 \\
Commercial mineral mix ${ }^{3}$ & 0.5 & 0.36 & 0.96 & 0.0 \\
Commercial protein supplement & 0.0 & 0.8 & 0.0 & \\
\hline
\end{tabular}

${ }^{1} \mathrm{LE}=$ low-energy, far-off diet; $\mathrm{ME}=$ moderate-energy, close-up diet; Postfresh = postfresh diet from 1 to 30 DIM; Lactation = lactation diet beginning at 30 DIM.

${ }^{2}$ Weighback from all lactating groups.

${ }^{3}$ Commercial mineral mix contained Rumensin (CP Feeds, Valders, WI) at the level of $0.15 \%$ of DM for the LE, ME, and postfresh diets.

hibitor. Samples were centrifuged $(915 \times g)$ at room temperature for 5 min immediately after collection; plasma was decanted and stored at $-20^{\circ} \mathrm{C}$ until analysis. Initially, 30 random plasma samples (15 from each treatment group) were analyzed for NEFA (NEFA-C kit, Wako Chemical USA, Richmond, VA; Johnson and Peters, 1993). Then, a power calculation was done to determine the necessary sample size $(n=57$ per treatment to detect a treatment difference of $100 \mu \mathrm{Eq} / \mathrm{L}$ with $\beta=0.20$ ); consequently, a larger subset of samples was randomly selected for analysis.

Disorders and diseases were defined and determined by the management of the farm by using a combination of industry and farm definitions. Retained placenta was defined as the visible presence of fetal membranes at the vulva or identified in the uterus by vaginal examination more than $24 \mathrm{~h}$ after parturition. Metritis was defined as inflammation of the lining of the uterus as identified by vaginal examination and/or the presence of abnormal cervical or vaginal discharge. Metritis diagnosis took place between $\mathrm{d} 4$ and 15 after parturition. Cows were considered to be ketotic if milk production was less than $10 \mathrm{~kg}$ at the morning milking during the first 30 DIM. Decreased appetite, manure consistency, and milk yield were also used in the diagnosis of ketosis. KetoCheck powder (Great States Animal Health, St. Joseph, MO), which detects acetoacetate in milk, was the final of 3 criteria used to determine if a cow would be dosed with propylene glycol. Dosing a cow with propylene glycol was the determinant for a cow being called ketotic. Displaced abomasum was diagnosed as decreased appetite accompanied by an audible, highpitched tympanic resonance of the left abdominal wall. Mastitis was defined as visually abnormal milk secre- tions such as clots, flakes, or watery consistency from one or more quarters. Inflammation of a quarter was also used to diagnosis mastitis. Mastitis was diagnosed by the milkers, whereas all other disorders were diagnosed by the herd manager. A cull cow was one that died or was sold during the experiment. The cull rates for the treatments were obtained by dividing the number of cows removed from a treatment during the 300$d$ lactation phase of the study by the total cows assigned to a treatment. Data collected before the culling event were included in the statistical analysis.

\section{Statistical Analysis}

The SAS (SAS Institute, 1999) procedure LIFETEST was used for survival analysis and determination of median days dry. Differences in time-dependent data of median days dry were analyzed by Kaplan-Meier survival curve. The nonparametric test of 2 samples

Table 2. Chemical composition of diets

\begin{tabular}{lcccc}
\hline & \multicolumn{3}{c}{ Diet $^{1}$} \\
\cline { 2 - 5 } Composition & LE & ME & Postfresh & Lactation \\
\hline DM, \% as-fed & 58.0 & 57.0 & 54.0 & 51.0 \\
NE , Mcal/kg of $\mathrm{DM}^{2}$ & 1.34 & 1.56 & 1.58 & 1.65 \\
CP, \% of DM & 13.9 & 15.2 & 18.8 & 17.8 \\
NDF, \% of DM & 52.0 & 47.2 & 33.6 & 34.3 \\
NFC, \% of DM & 25.9 & 28.6 & 37.8 & 39.2 \\
Fat, \% of DM & 2.3 & 1.8 & 4.7 & 4.4 \\
Ash, \% of DM & 8.5 & 9.7 & 7.7 & 6.8 \\
\hline
\end{tabular}

${ }^{1} \mathrm{LE}$ = low-energy, far-off diet; $\mathrm{ME}$ = moderate-energy, close-up diet; Postfresh $=$ postfresh diet from 1 to 30 DIM; Lactation = lactation diet beginning at 30 DIM.

${ }^{2}$ Assumes $13.6 \mathrm{~kg}$ of DMI/d prefresh and $22.7 \mathrm{~kg}$ of DMI/d postfresh. 
obtained from survival analysis was tested for homogeneity by the Wilcoxon test (Wilcoxon, 1945). Data from milk yield, composition, and BCS were analyzed as repeated measures using the SAS procedure MIXED. To account for repeated measures, a SAS AR(1) error structure was used to adjust for autocorrelation (SAS Institute, 1999). Body condition scores were analyzed from $3 \mathrm{wk}$ prepartum until $10 \mathrm{wk}$ and data from pre- and postpartum were analyzed as separate data sets. The same statistical model was used for calving interval, previous lactation $305 \mathrm{ME}$, and NEFA concentration, except that time and any interaction with time were dropped from the model because there were no repeated measures. Additionally, cows were divided into 7 categories based on their actual days dry $(<21,21-27,28$ $34,35-41,42-48,49-55$, and $>55$ d) to compare postpartum yields for the categories. The respective $\mathrm{n}$ for each category was $19,38,154,149,61,138$, and 213 . A mixed effects model was used to statistically analyze SCM for differences between DP categories. Fixed effects in the statistical model included parity, time, category, and interaction of parity by category. Cow was treated as a random effect. For milk production parameters ( $\mathrm{n}=$ 391 vs. 390 for $\mathrm{T}$ and $\mathrm{S}$, respectively) and NEFA ( $\mathrm{n}=$ 57 vs. 57 for T and S, respectively), time was DIM and for BCS ( $\mathrm{n}=391$ vs. 390 for T and S, respectively), time was week.

Differences between treatments for the number of cows culled, the usage of bST, and the incidences of ketosis, displaced abomasum, metritis, retained placenta, and mastitis were examined by the SAS procedure PROC LOGISTIC. The model for each of these parameters involved the fixed effects of treatment, parity, time, interaction of parity by treatment and interaction of treatment by time.

All values are reported as least squares means \pm standard error (LSM \pm SE) unless noted otherwise. Significant differences were declared at $P<0.05$ for main effects and interactions and a tendency was declared at $0.05 \leq P<0.1$.

\section{RESULTS AND DISCUSSION}

Actual DP lengths were $55.8 \pm 6.7$ for $\mathrm{T}(\mathrm{n}=391)$ and $34.0 \pm 7.5 \mathrm{~d}$ for $\mathrm{S}(\mathrm{n}=390)$, respectively. Survival analysis indicated that median days dry were 57 and $34 \mathrm{~d}$ for T and S, respectively, and that $90 \%$ of cows on $\mathrm{T}$ had a DP length between 44 and $65 \mathrm{~d}$ (range $=6$ to $77 \mathrm{~d}$ ), whereas $90 \%$ of cows on S had a DP length between 20 and $45 \mathrm{~d}$ (range $=4$ to $69 \mathrm{~d}$ ).

Prepartum milk yield was $22 \pm 1.07 \mathrm{~kg} / \mathrm{d}$ during the additional $21 \mathrm{~d}$ of lactation for cows on S. Furthermore, primiparous cows $(n=216)$ assigned to $S$ produced more milk than multiparous cows $(\mathrm{n}=174)$ during the final
Table 3. Postpartum milk production from 1 to 300 DIM and milk composition from 1 to 100 DIM for cows assigned to a shortened (S) or traditional $(\mathrm{T})$ dry period management strategy

\begin{tabular}{|c|c|c|c|c|}
\hline \multirow[b]{2}{*}{ Item } & \multicolumn{2}{|c|}{ Treatments $^{1}$} & \multirow[b]{2}{*}{$\mathrm{SE}$} & \multirow[b]{2}{*}{$P$-value } \\
\hline & $\mathrm{S}$ & $\mathrm{T}$ & & \\
\hline Milk, ${ }^{1} \mathrm{~kg} / \mathrm{d}$ & 41.5 & 43.6 & 0.77 & 0.007 \\
\hline Milk $^{2} \mathrm{~kg} / \mathrm{d}$ & 37.7 & 39.5 & 0.53 & 0.001 \\
\hline $\mathrm{SCM},{ }^{1} \mathrm{~kg} / \mathrm{d}$ & 37.4 & 38.6 & 0.69 & 0.06 \\
\hline Fat, ${ }^{1} \mathrm{~kg} / \mathrm{d}$ & 1.42 & 1.46 & 0.02 & 0.14 \\
\hline Fat, ${ }^{1} \%$ & 3.52 & 3.45 & 0.05 & 0.17 \\
\hline Protein, ${ }^{1} \mathrm{~kg} / \mathrm{d}$ & 1.14 & 1.15 & 0.02 & 0.62 \\
\hline Protein, ${ }^{1} \%$ & 2.83 & 2.68 & 0.03 & $<0.001$ \\
\hline $\mathrm{IgG}, \mathrm{mg} / \mathrm{dL}$ & 5,616 & 5,849 & 229.6 & 0.31 \\
\hline $\mathrm{SCS}^{3}$ & 3.12 & 3.27 & 0.2 & 0.47 \\
\hline Mastitis, ${ }^{2}$ cases & 153 & 147 & & 0.94 \\
\hline
\end{tabular}

${ }^{1} 1$ to 100 DIM.

${ }^{2} 1$ to 300 DIM.

${ }^{3} \mathrm{SCS}=\log 2(\mathrm{SCC} / 100,000)+3$.

3 wk before dry off $(24.1 \pm 0.72$ vs. $19.8 \pm 0.80 \mathrm{~kg} / \mathrm{d} ; P$ $<0.001$ ), which probably reflects greater persistency of lactation. It has been reported that milk yield during the last $30 \mathrm{~d}$ before dry off is lower for multiparous cows than for primiparous cows when continuously milked (Annen et al., 2004; Rastani et al., 2007). However, in these studies, the parity difference was not observed when comparing the additional milk yield resulting from shortening the DP from 60 to $30 \mathrm{~d}$. Milk samples were not obtained for component analysis during the $21 \mathrm{~d}$ extended lactation. The additional milk from milking for 21 extra days averaged $466 \pm 15.8 \mathrm{~kg}$, which is similar to previous research. Gulay et al. (2003) and Rastani et al. (2005) reported, respectively, that reducing the DP from 60 to $30 \mathrm{~d}$ resulted in 510 and $422 \mathrm{~kg}$ of additional milk. Additional milk gained during the extended lactation needs to be taken into consideration when determining the optimal length of the DP.

Mean postpartum milk production was $2.1 \mathrm{~kg} / \mathrm{d}$ greater for management strategy $\mathrm{T}$ compared with $\mathrm{S}$ (43.6 vs. $41.5 \mathrm{~kg} / \mathrm{d} ; P=0.007$ ) for the first $100 \mathrm{DIM}$ (Table 3). Milk production was monitored through 300 DIM, and cows assigned to T produced more milk than cows assigned to $\mathrm{S}(39.5 \mathrm{vs} .37 .7 \mathrm{~kg} / \mathrm{d} ; P<0.001)$. The use of bST was not equal between treatments; more cows assigned to $\mathrm{S}$ received bST than cows assigned to T (42 vs. $33 \% ; ~ P<0.001$ ); however, there was no treatment by bST interaction. Funk et al. (1987) indicated that cows given a DP between 60 and $69 \mathrm{~d}$ produced $459 \mathrm{~kg}$ more milk in the subsequent lactation than those given a $\mathrm{DP}<40 \mathrm{~d}$. Others have reported a loss in milk yield when the DP is reduced to less than $40 \mathrm{~d}$ (Coppock et al., 1974; Remond et al., 1997; Rastani et al., 2005). For example, Rastani et al. (2005) reported that cows given a 28-d DP produced significantly less milk (37.9 vs. $42.2 \mathrm{~kg} / \mathrm{d}$ for 28 - and $56-\mathrm{d} \mathrm{DP}$, respectively) than 
Table 4. Postpartum milk production according to parity when cows are assigned to a shortened (S) or traditional $(\mathrm{T})$ dry period management strategy

\begin{tabular}{|c|c|c|c|c|c|c|c|c|c|}
\hline \multirow[b]{2}{*}{ Item } & \multicolumn{4}{|c|}{ Parity 2} & \multicolumn{4}{|c|}{ Parity $3+$} & \multirow{2}{*}{$\begin{array}{c}\text { Treatment } \times \\
\text { parity } \\
\text { interaction } \\
P \text {-value }\end{array}$} \\
\hline & $\mathrm{T}$ & $\mathrm{S}$ & $\mathrm{SE}$ & $P$-value & $\mathrm{T}$ & $\mathrm{S}$ & $\mathrm{SE}$ & $P$-value & \\
\hline $\mathrm{n}$ & 210 & 216 & & & 181 & 174 & & & \\
\hline Milk, ${ }^{1} \mathrm{~kg} / \mathrm{d}$ & 42.3 & 39.0 & 1.02 & 0.001 & 44.8 & 44.0 & 1.12 & 0.47 & 0.08 \\
\hline $\mathrm{SCM},{ }^{1} \mathrm{~kg} / \mathrm{d}$ & 37.50 & 35.20 & 0.91 & 0.01 & 39.8 & 39.5 & 0.99 & 0.77 & 0.13 \\
\hline Fat, ${ }^{1} \mathrm{~kg} / \mathrm{d}$ & 1.41 & 1.32 & 0.04 & 0.04 & 1.52 & 1.52 & 0.05 & 0.85 & 0.19 \\
\hline Fat, ${ }^{1} \%$ & 3.40 & 3.47 & 0.07 & 0.26 & 3.51 & 3.58 & 0.08 & 0.40 & 0.88 \\
\hline Protein, ${ }^{1} \mathrm{~kg} / \mathrm{d}$ & 1.14 & 1.1 & 0.03 & 0.17 & 1.17 & 1.19 & 0.03 & 0.57 & 0.17 \\
\hline Protein, ${ }^{1} \%$ & 2.71 & 2.88 & 0.03 & $<0.001$ & 2.64 & 2.77 & 0.04 & 0.005 & 0.50 \\
\hline $\mathrm{SCS}^{2}$ & 3.09 & 3.9 & 0.25 & 0.45 & 3.44 & 3.45 & 0.73 & 0.65 & 0.65 \\
\hline
\end{tabular}

${ }^{1} 1$ to 100 DIM.

${ }^{2} \mathrm{SCS}=\log 2(\mathrm{SCC} / 100,000)+3$.

those cows assigned to a 56-d DP. Sorensen and Enevoldsen (1991) also reported that when the DP was reduced from 10 or 7 wk to 4 wk there was a loss in milk yield by dual-purpose Danish cows. In contrast, Gulay et al. (2003) reported that milk yield did not differ when comparing a 30 - to $60-\mathrm{d}$ DP $(38.4 \mathrm{vs} .38 .7 \mathrm{~kg} / \mathrm{d}$, respectively).

There was a tendency for a parity by treatment interaction for postpartum milk production $(P=0.08)$ and SCM $(P=0.13$; Table 4$)$. Treatment differences were not observed for cows in their third or greater lactation, but were detected for cows in their second lactation. Our data agreed with that of Annen et al. (2004) who reported that reducing DP length from 60 to $30 \mathrm{~d}$ significantly affects second-lactation cows but not third and greater lactation cows. A recent retrospective analysis of farm records indicated that milk yields from cows in their third lactation or greater are not affected by DP length whereas those in their second lactation are affected by DP length (Kuhn et al., 2006). Dias and Allaire (1982) determined that as age during the preceding lactation increased, the length of DP necessary to achieve maximum milk yield over 2 consecutive lactations decreased. Sorensen and Enevoldsen (1991) and Rastani et al. (2005) did not detect a treatment by parity interaction for milk production. Our research supports the idea that as cows increase in lactation number, fewer days dry are required to maximize milk yield during the subsequent lactation.

Our study was designed to compare 2 different DP management strategies, but it also allowed us to examine milk production of cows that experienced different dry period lengths. Our categorical analysis of data from all cows indicated that there was no loss in SCM yield until days dry was less than 21 (Table 5). Within parity 2, significantly less SCM was produced when days dry were less than 21 (Table 5). For parity $3+$ cows, SCM yield was also lowest for cows less than
21 d dry, although not significantly different from all categories. Categorical analysis for milk yield showed similar results (data not shown). Previous research (Kuhn et al., 2006) indicated that when days dry are less than 56, a loss in milk production occurs during the subsequent lactation.

Previous research (Dias and Allaire, 1982) indicated DP length might affect the level of milk production differently depending on length of the calving interval. It was reported that when the calving interval was less than $340 \mathrm{~d}$, a DP of at least $55 \mathrm{~d}$ was required to maximize milk production during 2 consecutive lactations (Dias and Allaire, 1982). There was a tendency for the calving interval to be longer for cows assigned to T compared with $\mathrm{S}(375 \pm 1.97$ vs. $370 \pm 1.98 ; P<0.10)$.

Milk fat yield did not differ $(P=0.14)$ between DP management strategies (Table 3). Other studies have shown either no difference or a slight decrease in milk fat yield when the DP is reduced (Sorensen and Enevoldsen, 1991; Gulay et al., 2003; Rastani et al., 2005). Recent retrospective analysis (Kuhn et al., 2006) indicated that milk fat yield was not affected by DP length unless the DP was less than $20 \mathrm{~d}$, at which point secondlactation cows are more negatively affected than third or greater lactation cows.

Milk fat percentage was not affected by DP management strategy $(P=0.17 ; 3.45 \pm 0.04$ vs. $3.52 \pm 0.04 \%$ for $\mathrm{T}$ and $\mathrm{S}$, respectively) during the initial $100 \mathrm{DIM}$ (Table 3). This agrees with most previous data (Lotan and Adler, 1976; Gulay et al., 2003; Annen et al., 2004) but is in contrast to Rastani et al. (2005), who observed that milk fat percentage increased from 3.86 to $4.08 \%$ during early lactation when the DP was reduced from 56 to $28 \mathrm{~d}$. There was no treatment by parity interaction for either milk fat yield or milk fat percentage in this experiment.

Milk protein yield did not differ $(P=0.62)$ between DP management strategies; however, milk protein per- 
Table 5. Solids-corrected milk by days dry category of $(<21,21-27,28-34,35-41,42-48$, 49-55, and $>55$ d) for cows assigned to a shortened 34-d (S) or traditional 55-d (T) dry period

\begin{tabular}{|c|c|c|c|c|c|c|c|c|c|}
\hline \multirow[b]{2}{*}{ Category } & \multicolumn{3}{|c|}{ All cows } & \multicolumn{3}{|c|}{ Parity 2} & \multicolumn{3}{|c|}{ Parity 3+ } \\
\hline & $\begin{array}{l}\text { Milk } \\
\text { yield }\end{array}$ & $\mathrm{SE}$ & $\begin{array}{c}\mathrm{n}= \\
(\text { Total/T/S })^{1}\end{array}$ & $\begin{array}{l}\text { Milk } \\
\text { yield }\end{array}$ & $\mathrm{SE}$ & $\begin{array}{c}\mathrm{n}= \\
(\text { Total/T/S) }\end{array}$ & $\begin{array}{l}\text { Milk } \\
\text { yield }\end{array}$ & $\mathrm{SE}$ & $\begin{array}{c}\mathrm{n}= \\
\text { (Total/T/S) }\end{array}$ \\
\hline$<21$ & $30.8^{\mathrm{a}}$ & 2.43 & $19 / 1 / 18$ & $9.1^{\mathrm{a}}$ & 2.58 & $13 / 1 / 12$ & $32.6^{\mathrm{a}}$ & 3.9 & $6 / 0 / 6$ \\
\hline $21-27$ & $39.2^{\mathrm{b}}$ & 1.82 & $38 / 2 / 36$ & $38.6^{\mathrm{b}}$ & 2.04 & $24 / 2 / 22$ & $39.8^{\mathrm{ab}}$ & 2.75 & $14 / 0 / 14$ \\
\hline $28-34$ & $39.8^{\mathrm{b}}$ & 1.14 & $154 / 2 / 152$ & $37.2^{\mathrm{b}}$ & 1.29 & $88 / 1 / 87$ & $42.3^{\mathrm{b}}$ & 1.41 & $66 / 1 / 65$ \\
\hline $35-41$ & $38.8^{b}$ & 1.13 & $149 / 6 / 143$ & $36.0^{\mathrm{b}}$ & 1.32 & $81 / 2 / 79$ & $41.7^{\mathrm{b}}$ & 1.37 & $68 / 4 / 64$ \\
\hline $42-48$ & $38.3^{b}$ & 1.21 & $60 / 28 / 32$ & $37.1^{\mathrm{b}}$ & 1.56 & $33 / 20 / 13$ & $39.6^{\mathrm{ab}}$ & 1.86 & $27 / 8 / 19$ \\
\hline $49-55$ & $37.6^{\mathrm{b}}$ & 1.18 & $137 / 133 / 4$ & $37.2^{\mathrm{b}}$ & 1.32 & $81 / 78 / 3$ & $38.3^{\mathrm{ab}}$ & 1.48 & $56 / 55 / 1$ \\
\hline$>55$ & $38.8^{\mathrm{b}}$ & 1.09 & $213 / 208 / 5$ & $37.6^{\mathrm{b}}$ & 1.27 & $97 / 97 / 0$ & $39.9^{\mathrm{ab}}$ & 1.22 & $116 / 111 / 5$ \\
\hline
\end{tabular}

${ }^{\mathrm{a}, \mathrm{b}}$ Means with different letters within column differ at $P<0.05$.

${ }^{1}$ Number of total cows or cows assigned to $\mathrm{S}$ or $\mathrm{T}$ dry period.

centage was greater $(P<0.001)$ for cows assigned to $\mathrm{S}$ compared with those assigned to $\mathrm{T}(2.68 \pm 0.02 \mathrm{vs} .2 .83$ $\pm 0.02 \%$; Table 3). Sorensen and Enevoldsen (1991) reported that milk protein yield was increased when cows were given a traditional DP compared with a shortened DP. Losses in milk protein yield were seen when DP was $>60 \mathrm{~d}$ or $<20 \mathrm{~d}$, with the greatest reduction in yield seen when DP was $<20$ d (Kuhn et al., 2006). Rastani et al. (2005) reported an increase in milk protein percentage when the DP was reduced from 56 to $28 \mathrm{~d}$. One possible reason for the increase in protein percentage could be an improved EB, which spares amino acids and energy for protein synthesis (Remond and Bonnefoy, 1997).

There was a tendency $(P=0.06)$ for cows assigned to $\mathrm{T}$ to produce more SCM than cows assigned to $\mathrm{S}(38.6$ vs. $37.4 \mathrm{~kg} / \mathrm{d}$, respectively; Table 3). Recently, Rastani et al. (2005) reported no difference in SCM yield when comparing 28- to 56 -d DP (37.6 vs. $39.9 \mathrm{~kg} / \mathrm{d}$ for 28 and $56 \mathrm{~d}$, respectively). Gulay et al. (2003) reported no difference in 3.5\% FCM yield when cows were given a 30- or 60-d DP; however, Sorensen and Enevoldsen (1991) indicated that 4\% FCM yield decreased when the DP was reduced from 7 or $10 \mathrm{wk}$ to $4 \mathrm{wk}$. It should be noted that our data indicated that there was a tendency for a decrease in SCM even though the treatment difference in SCM yield was less than that of Rastani et al. (2005), who reported no difference. The increased animal numbers on our experiment allowed greater sensitivity to detect treatment differences.

Colostrum quality was measured by IgG concentration and no differences ( 5,849 vs. $5,616 \mathrm{mg} / \mathrm{dL}$ for cows assigned to $\mathrm{T}$ and $\mathrm{S}$, respectively; $P=0.31$ ) were detected between treatments (Table 3). Similar results were obtained by others (Annen et al., 2004; Rastani et al., 2005) when DP was reduced from 60 and $56 \mathrm{~d}$ to 30 and $28 \mathrm{~d}$, respectively. When cows are continuously milked, increased milk production at parturition may negatively affect colostrum quality by diluting IgG in colostrum (Rastani et al., 2005). This does not seem to be the case when there is at least a 4-wk DP. Therefore, a traditional and a reduced DP should result in colostrum that supplies sufficient amounts of IgG to the calf.

Shortening the DP to $34 \mathrm{~d}$ did not affect SCS through 100 DIM $(P=0.47)$ or the incidence of mastitis through 300 DIM in the subsequent lactation $(P=0.94$; Table 3 ), which agrees with previous research (Enevoldsen and Sorensen, 1992; Remond et al., 1992; Gulay et al., 2003; Annen et al., 2004). Rastani et al. (2005) indicated a tendency $(P<0.15)$ for lower SCS when the DP was reduced from 56 to $28 \mathrm{~d}$ (3.37 vs. 2.56). Retrospective analysis of data from commercial farms has shown that a DP of $60 \mathrm{~d}$ or less resulted in a higher overall SCS in the subsequent lactation (Kuhn et al., 2006). Kuhn et al. (2006) also reported that a DP of less than $20 \mathrm{~d}$ had a more adverse effect on SCS for cows in their second lactation compared with those in their third or greater lactation. However, in planned research experiments, shortening the DP seems to have no negative effect on SCS in the subsequent lactation.

\section{Energy Balance and Health Parameters}

During the entire course of the study, mean BCS did not differ $(P=0.40)$ between cows assigned to $\mathrm{T}$ or $\mathrm{S}$ (3.23 \pm 0.02 vs. $3.25 \pm 0.01$; Figure 1). Mean BCS for wk $-4,0$, and 9 were $3.75 \pm 0.03$ vs. $3.65 \pm 0.03,3.37$ \pm 0.02 vs. $3.38 \pm 0.03$, and $2.89 \pm 0.03$ vs. $2.93 \pm 0.03$ for cows assigned to T and S, respectively. Prepartum, there was a difference in BCS among cows assigned to T and $\mathrm{S}(3.75 \pm 0.01$ vs. $3.69 \pm 0.01$, respectively; $P<$ 0.01). Postpartum, there was also a difference detected in BCS among cows assigned to $\mathrm{T}$ and $\mathrm{S}(3.01 \pm 0.02$ vs. $3.07 \pm 0.01$, respectively; $P=0.03$ ). Although there was a significant difference detected in BCS among treatments during the prepartum and postpartum periods, it should be noted that the difference was less than one-tenth of a point during each time period. The 


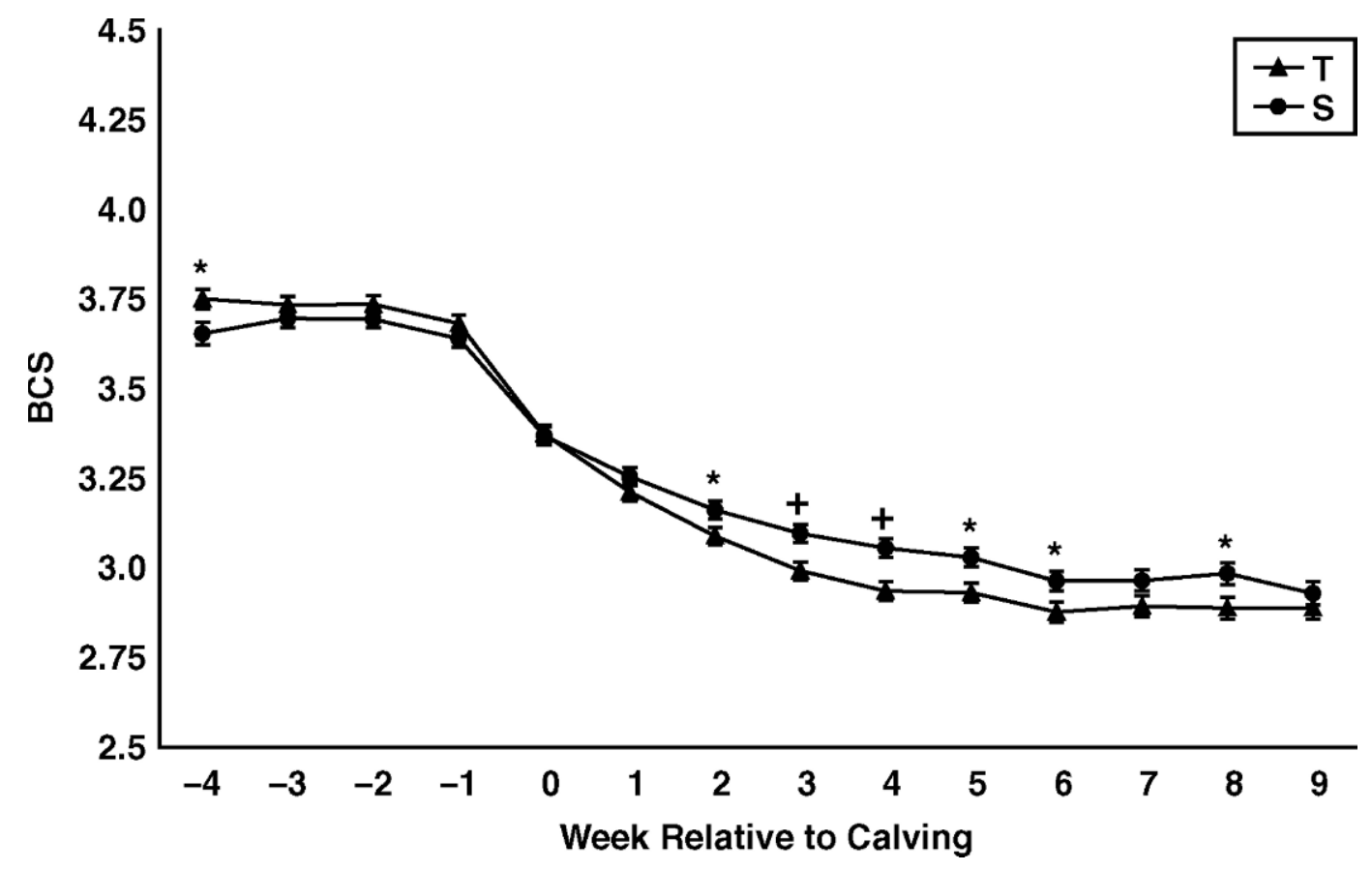

Figure 1. Body condition scores for cows assigned to a shortened $(\mathrm{S} ; \bullet)$ or traditional $(\mathrm{T} ; \mathbf{\Delta})$ dry period management strategy. $*$ and + indicate differences between treatments at $P<0.05$ and $P<0.01$, respectively.

maximum difference in BCS seen between treatments was during wk 4 after calving and the difference was 0.12 points. There was a significant treatment by time interaction $(P=0.001)$ when data from the entire period from wk 4 prepartum until wk 9 postpartum was analyzed. When BCS data from prepartum and postpartum were analyzed separately, there were no treatment by time interactions. Body condition score was highest during wk 4 before expected calving (3.75) and lowest during wk 6 postpartum (2.88) for cows assigned to T. Cows assigned to $\mathrm{S}$ displayed the highest BCS score during wk 3 before expected calving (3.70) and the lowest BCS during wk 9 postpartum (2.93).

Plasma NEFA concentration is an indicator of fat mobilization (Whitaker et al., 1999; Ingvartsen and Andersen, 2000; Seifi et al., 2007); 3 wk before expected parturition it tended to be lower for cows assigned to T relative to cows assigned to $\mathrm{S}(155 \mathrm{vs.} 185 \mu \mathrm{Eq} / \mathrm{L} ; P=$ 0.09). Rastani et al. (2005) reported that prepartum NEFA concentrations increased from 5 to 1 wk prepartum with the greatest increase occurring in cows with a 56-d DP (128, 34, and $27 \mu \mathrm{Eq} / \mathrm{L}$ increase for 56,28 , and $0 \mathrm{~d}$ dry, respectively). Postpartum NEFA concentrations were lower for cows assigned to $\mathrm{S}$ compared with T (337.4 vs. $428.8 \mu \mathrm{Eq} / \mathrm{L} ; P=0.02$ ). Rastani et al. (2005) reported that postpartum plasma NEFA concentration did not differ when the DP was reduced from 56 to 28 d; however, concentrations were lower for cows with 0 -d DP compared with $28-d$ DP (235 vs. $394 \mu E q /$ L). The greater postpartum NEFA concentration seen for $\mathrm{T}$ suggests a greater rate of fat mobilization and perhaps greater NEB. Because cows on both treatments were housed together in group pens, it was not possible to measure DMI or estimate EB. Lower postpartum milk yield for cows on S may have affected EB and contributed to the lower NEFA concentration.

The incidences of ketosis (18.6 vs. $18.5 \%$ ), metritis (19.6 vs. $15.6 \%)$, retained placenta ( 8.9 vs. $9.5 \%)$, and displaced abomasum (5.5 vs. $6.2 \%$ ) for $\mathrm{T}$ and $\mathrm{S}$, respectively, were not affected by treatment $(P>0.15)$. This experiment is 1 of only 2 studies that have assessed the effect of DP length on the incidence rates of metabolic disorders. Coppock et al. (1974) evaluated DP lengths of $20,30,40,50$, and $60 \mathrm{~d}$ and found no difference in the incidence rate of over 20 different disorders. There was a trend for a decrease in cases of ketosis as the DP was decreased (Coppock et al., 1974). For the entire lactation, more cows on $\mathrm{T}$ were culled than cows on $\mathrm{S}$ (22 vs. $13 \% ; P<0.004)$. The majority of cows culled from the experiment were culled for mastitis, reproduction, or feet and leg problems (35\% mastitis, 18\% reproduction, and $14 \%$ feet and leg). Percentage of cows culled during the first 30 DIM did not differ between treatments ( 4.7 vs. $5.1 \% ; P=0.87$ ). Metabolic status as indicated by postpartum plasma NEFA concentration 
was improved in cows on $\mathrm{S}$, but this did not translate into a reduction in metabolic disorders or 30 -d cull rate.

\section{CONCLUSIONS}

Reducing targeted DP length from 55 to $34 \mathrm{~d}$ decreased milk yield, had a tendency to decrease SCM and increased milk protein percentage during the subsequent lactation. The reductions in milk and SCM yield were accounted for by cows in their second lactation, with no effect of DP management strategy on yield for cows in their third or greater lactation. Analysis of SCM yield by different categories of DP length indicated that it was not compromised until DP length fell below $21 \mathrm{~d}$, irrespective of parity. Colostrum quality was not influenced by DP length. In general, the effects of reducing the DP length on lactation performance were consistent with previous trials. Reducing the DP length decreased NEFA concentration at $3 \mathrm{wk}$ postpartum; however, incidence of metabolic disorders was not affected. Reducing the DP did not appear to improve or reduce animal health during the subsequent lactation. Results indicate that dairy producers have flexibility in managing DP length, especially when the additional milk obtained through the extension of the current lactation is also considered.

\section{ACKNOWLEDGMENTS}

We would like to thank Hubbard Feeds Inc. (Mankato, MN), MSC Specialty Nutrition (Dundee, IL), Monsanto Dairy Business (St. Louis, MO), Pioneer Hi-Bred International Inc. (Johnson, IA), Vita Plus Corp. (Madison, WI), and West Central (Ralston, IA) for their financial support and guidance during the experiment. Support was also provided by Joe Drexler and Fox Valley DHIA, as well as Bou-matic (Madison, WI) who very generously donated milking equipment to aid in the collection of milk samples. Special thanks to Mattias Aguerre, Tanya Gressley, Nelson Lobos, Jose Pires, Eric Schwab, Ryan Sterry, and Noelia Silva del Rio for helping with sample collection. Finally, thanks to Kenn Buelow, Jackie Schnackel, Dennis Zweber, and Chris Ditter for their help and support at Holsum Dairies, LLC (Hilbert, WI).

\section{REFERENCES}

Annen, E. L., R. J. Collier, M. A. McGuire, J. L. Vicini, J. M. Ballam, and M. J. Lormore. 2004. Effect of modified dry period lengths and bovine somatotropin on yield and composition of milk from dairy cows. J. Dairy Sci. 87:3746-3761.

AOAC. 1999. Official Methods of Analysis. AOAC, Arlington, VA.

Bachman, K. C., and M. L. Schairer. 2003. Invited review: Bovine studies on optimal lengths of dry periods. J. Dairy Sci. 86:3027-3037.
Bertics, S. J., R. R. Grummer, C. Cadorniga-Valino, and E. E. Stoddard. 1992. Effect of prepartum dry matter intake on liver triglyceride concentration and early lactation. J. Dairy Sci. 75:19141922.

Coppock, C. E., R. W. Everett, R. P. Natzke, and H. R. Ainslie. 1974. Effect of dry period length on Holstein milk production and selected disorders at parturition. J. Dairy Sci. 57:712-718.

Dias, F. M., and F. R. Allaire. 1982. Dry period to maximize milk production over 2 consecutive lactations. J. Dairy Sci. 65:136-145.

Enevoldsen, C., and J. T. Sorensen. 1992. Effects of dry period length on clinical mastitis and other major clinical health disorders. J. Dairy Sci. 75:1007-1014.

Fleenor, W. A., and G. H. Stott. 1981. Single radial immunodiffusion analysis for quantitation of colostral immunoglobulin concentration. J. Dairy Sci. 64:740-747.

Funk, D. A., A. E. Freeman, and P. J. Berger. 1987. Effects of previous days open, previous days dry, and present days open on lactation yield. J. Dairy Sci. 70:2366-2373.

Gearhart, M. A., C. R. Curtis, H. N. Erb, R. D. Smith, C. J. Sniffen, L. E. Chase, and M. D. Cooper. 1990. Relationship of changes in condition score to cow health in Holsteins. J. Dairy Sci. 73:3132-3140.

Goff, J. P., and R. L. Horst. 1997. Physiological changes at parturition and their relationship to metabolic disorders. J. Dairy Sci. 80:1260-1268.

Gulay, M. S., M. J. Hayen, K. C. Bachman, T. Belloso, M. Liboni, and H. H. Head. 2003. Milk production and feed intake of Holstein cows given short (30-d) or normal (60-d) dry periods. J. Dairy Sci. 86:2030-2038.

Gümen, A., R. R. Rastani, R. R. Grummer, and M. C. Wiltbank. 2005. Reduced dry periods and varying prepartum diets alter postpartum ovulation and reproductive measures. J. Dairy Sci. 88:2401-2411.

Hayirli, A., and R. R. Grummer. 2004. Factors affecting dry matter intake prepartum in relationship to etiology of peripartum lipidrelated metabolic disorders: A review. Can. J. Anim. Sci. 84:337-347.

Ingvartsen, K. L., and J. B. Andersen. 2000. Integration of metabolism and intake regulation: A review focusing on periparturient animals. J. Dairy Sci. 83:1573-1597.

Johnson, M. M., and J. P. Peters. 1993. An improved method to quantify nonesterified fatty acids in bovine plasma. J. Anim. Sci. $71: 753-756$.

Kuhn, M. T., and J. L. Hutchison. 2005. Methodology for estimation of days dry effects. J. Dairy Sci. 88:1499-1508.

Kuhn, M. T., J. L. Hutchison, and H. D. Norman. 2006. Effects of dry period length on yields of milk fat and protein, fertility and milk somatic cell score in the subsequent lactation of dairy cows. J. Dairy Res. 73:154-162.

Lotan, E., and J. H. Adler. 1976. Observations on the effect of shortening the dry period on milk yield, body weight, and circulating glucose and FFA levels in dairy cows. Tijdsch. Diergeneeskd. 101:77-82.

National Forage Testing Association. 1993. Forage Analysis Procedures. NFTA, Omaha, NE.

Rastani, R. R. 2005. Effects of varying dry period length on lactation performance, efficiency of production and reproduction, and energy status of dairy cattle. $\mathrm{PhD}$ Thesis. University of Wisconsin, Madison.

Rastani, R. R., N. S. del Rio, T. F. Gressley, G. E. Dahl, and R. R. Grummer. 2007. Effects of increasing milking frequency during the last 28 days of gestation on milk production, dry matter intake, and energy balance in dairy cows. J. Dairy Sci. 90:17291739 .

Rastani, R. R., and R. R. Grummer. 2006. Consequences of shortening the dry period in dairy cows. Chapter 13 inRecent Advances in Animal Nutrition, 2005. C. Garnsworthy and J. Wiseman, ed. Nottingham Univ. Press., Nottingham, UK.

Rastani, R. R., R. R. Grummer, S. J. Bertics, A. Gümen, M. C. Wiltbank, D. G. Mashek, and M. C. Schwab. 2005. Reducing dry period length to simplify feeding transition cows: Milk production, 
energy balance, and metabolic profiles. J. Dairy Sci. 88:10041014.

Remond, B., and J. C. Bonnefoy. 1997. Performance of a herd of Holstein cows managed without the dry period. Ann. Zootech. $46: 3-12$.

Remond, B., J. Kerouanton, and V. Brocard. 1997. The effect of reducing or omitting the dry period on the performance of dairy cows. Prod. Anim. 10:301-315.

Remond, B., A. Ollier, and G. Miranda. 1992. Milking of cows in late pregnancy-Milk production during this period and during the succeeding lactation. J. Dairy Res. 59:233-241.

Ruegg, P. L., W. J. Goodger, C. A. Holmberg, L. D. Weaver, and E. M. Huffman. 1992. Relation among body condition score, serum urea nitrogen and cholesterol concentrations, and reproductiveperformance in high-producing Holstein dairy-cows in early lactation. Am. J. Vet. Res. 53:10-14.

SAS Institute. 1999. User's Guide: Statistics. Version 8 ed. SAS Institute, Cary, NC.
Seifi, H., M. Gorji-Dooz, M. Mohri, B. Dalir-Naghadeh, and N. Farzaneh. 2007. Variations of energy-related biochemical metabolites during transition period in dairy cows. Comp. Clin. Pathol. 16:253-258.

Sorensen, J. T., and C. Enevoldsen. 1991. Effect of dry period length on milk production in subsequent lactation. J. Dairy Sci. 74:1277-1283.

Whitaker, D. A., W. J. Goodger, M. Garcia, B. Perera, and F. Wittwer. 1999. Use of metabolic profiles in dairy cattle in tropical and subtropical countries on smallholder dairy farms. Prev. Vet. Med. 38:119-131.

Wilcoxon, F. 1945. Individual comparison by ranking methods. Biometrics 1:80-83.

Wildman, E. E., G. M. Jones, P. E. Wagner, R. L. Boman, H. F. Troutt Jr., and T. N. Lesch. 1982. A dairy cow body condition scoring system and its relation to selected production characteristics. J. Dairy Sci. 65:495-501. 